\title{
Energy conservation in malolactic fermentation by Lactobacillus plantarum and Lactobacillus sake
}

\author{
Sylvie Kolb, Hubert Otte, Barbara Nagel, and Bernhard Schink \\ Lehrstuhl Mikrobiologie I der Eberhard-Karls-Univerșität, Auf der Morgenstelle 28. W-7400 Tübingen, Federal Republic of Germany
}

Received December 9, 1991/Accepted January 23, 1992

\begin{abstract}
A comparably poor growth medium containing $0.1 \%$ yeast extract as sole non-defined constituent was developed which allowed good reproducible growth of lactic acid bacteria. Of seven different strains of lactic acid bacteria tested, only Lactobacillus plantarum and Lactohacillus sake were found to catalyze stoichiometric conversion of L-malate to L-lactate and $\mathrm{CO}_{2}$ concomitant with growth. The specific growth yield of malate fermentation to lactate at $\mathrm{pH} 5.0$ was $2.0 \mathrm{~g}$ and $3.7 \mathrm{~g}$ per mol with $L$. plantarum and L. sake, respectively. Growth in batch cultures depended linearly on the malate concentration provided. Malate was decarboxylated nearly exclusively by the cytoplasmically localized malo-lactic enzyme. No other $\mathrm{C}_{4}$-dicarboxylic acid-decarboxylating enzyw me activity could be detected at significant activity in cell-free extracts. In pH-controlied continuous cultures, L. plantarum grew well with glucose as substrate, but not with malate. Addition of lactate to continuous cultures metabolizing glucose or malate decreased cell yields significantly. These results indicate that malo-lactic fermentation by these bacteria can be coupled with energy conservation, and that membrane energetization and ATP synthesis through this metabolic activity are due to malate uptake and/or lactate excretion rather than to an ion-translocating decarboxylasc enzyme.
\end{abstract}

Key words: Malo-lactic fermentation - Bioenergetics Transport-coupled energetization - Continuous culture - Malo-lactic enzyme - Oxalo-acetate decarboxylase

Fermentative conversion of $\mathrm{L}$-malate to L-lactate is called malo-lactic fermentation (Kunkee 1967) and is a wellknown and important process during the so-called "secondary" acid-degrading fermentation which follows the primary alcoholic fermentation in wine making (Davis et al. 1985; Wibowo et al. 1985). Since malic acid makes up about half of the total acid content of the must, malo-lactic fermentation contributes considerably to the deacidification of wine and, with this, to its flavour quality and stability. Already to the end of the last century, lactic acid bacteria were found to carry out this important reaction (Koch 1898, 1900; Müller-Thurgau and Osterwalder 1913).

Conversion of malate to lactate through malo-lactic fermentation does not yield products for further energy generation and, at least at lirst sight, the process does not provide an obvious advantage to the bacteria. Simultaneous fermentation of L-malate and D-glucose by a Leuconostoc mesenteroides strain in a complex medium did not result in a quantitative or qualitative change of the fermentation products or cell yields (Kandler et al. 1973), and it was concluded that malo-lactic fermentation does not provide energy for growth. This view is also maintained in textbooks (c.g. Gottschalk 1979), however, it is now expressed less definitively (Gottschalk 1986). Il is assumed that the physiological significance of this fermentation which is wide-spread among lactic acid bacteria should be mainly the decrease of acidity to compensate excess proton activity (Doelle 1975).

Indications of energy conservation through malolactic fermentation was obtained recently by assays of ATP contents in lactic acid bacteria in the presence or absence of malate (Cox and Henick-Kling 1989). Since the free energy change of the decarboxylation reaction is small $\left(\Delta \mathrm{G}^{0 \prime}=-26.5 \mathrm{~kJ}\right.$ per mol; Thauer et al. 1977), energy conservation could be associated only with the generation of a chemiosmotic gradient across the cytoplasmic nembrane. Fermentative energy conservation through decarboxylation of dicarboxylic acids has been reported in the recent past for oxalate (Dawson et al. 1980; Smith et al. 1985; Dehning and Schink 1989a), malonate (Dehning and Schink $1989 \mathrm{~b}$; Dehning et al. 1989), succinate (Schink and Pfennig 1982; Denger and Schink 1990), and glutarate (Matthies and Schink 1992). In all cases, a fraction of an ATP equivalent was conserved, and molar growth yields in the range of $0.9 .3 .5 \mathrm{~g}$ dry cell matter were observed.

In the present paper, various strains of lactic acid bacteria were checked for their ability to grow by malate decarboxylation to lactate. 


\section{Materials and methods}

\author{
Sources of arganisms
}

Lactobacillus casei (DSM 20008), Lactobacillus corymformis (DSM 20005), Leuconastoc mesenteroides (DSM 20343) and Lactobacillus sake (DSM 20017) were obtained from the Deutsche Sammlung für Mikroorganismen und Zellkulturen GmbH, Braunsthweig, FRG. Lactobacillus plantarum strain B 38 was kindly provided by Prof. F. Radler, Mainz, FRG, Lactobccillus spee. (DSM 20252) by Dr. N. Weiss, Weihenstephan, FRG, and Streptococcus faecalis, 10C1, by Dr. P. van Demark, Cornell University, Ithaca, New York, USA.

\section{Media and growth conditions}

For anaerobic cultivation of lactic acid bacteria, cystein-redaced $(2.8 \mathrm{mM})$ muneral salts media with $0.1 \%$ yeast cxtract and further supplements were used. Media were prepared anoxically after Widdel and Pfennig (1981). The following components were used (per liter): a) medium with final pll 6.4: $\mathrm{KH}_{2} \mathrm{PO}_{4}, 6.8 \mathrm{~g} ; \mathrm{NH}_{4} \mathrm{Cl}$, $\left.1.0 \mathrm{~g}, \mathrm{MgSO}_{4} \times 7 \mathrm{H}_{2} \mathrm{O}, 0.2 \mathrm{~g} ; \mathrm{MnSO}_{4} \times \mathrm{H}_{2} \mathrm{O}, 0.05 \mathrm{~g} ; \mathrm{b}\right)$ medium with final $\mathrm{pH} 5.0: \mathrm{KH}_{2} \mathrm{PO}_{4}, 0.68 \mathrm{~g} ; \mathrm{Na}_{2}$-succinate, $6.75 \mathrm{~g} ; \mathrm{NH}_{4} \mathrm{Cl}$, $1.0 \mathrm{~g} ; \mathrm{MgSO}_{4} \times 7 \mathrm{H}_{2} \mathrm{O}, 0.2 \mathrm{~g} ; \mathrm{MnSO}_{4} \times \mathrm{H}_{2} \mathrm{O}, 0.05 \mathrm{~g}$. Low-sodium media were prepared with the respective potassium salts. After attoclaving; media were supplemented with $1 \mathrm{ml}$ of trace element solution SL 10 (Widdel et al. 1983) per liter, as well as $0.5 \mathrm{~m} / 1$ of ten-fold concentrated 7 -vilamins solution (Widdel and Pfennig 1981). Substrates were added from concentrated sterile stock solutions before inoculation. Growth was followed via turbidity in $22-\mathrm{ml}$ screw-cap tubes with a Spectronic 20 Spectrophotometer (Milton Roy, Rochester. NY, USA) at $450 \mathrm{~nm}$ or $546 \mathrm{~nm}$. Culture purity was checked microscopically after growth in the above media or on agar plates with a complex medium (Evans and Niven 1951).

'Fxperiments in $\mathrm{pH}$-comtrolled batsh and contintous culture were performed at $30^{\circ} \mathrm{C}$ with the phosphate-buffered medium in an anaerobic chemostat system with $640-\mathrm{ml}$ working volume without headspace. The $\mathrm{pH}$ was maintained at pH 5.7 with $1 \mathrm{MHCl}$ or $1 \mathrm{M} \mathrm{NaOH}$ by a laboratory pIt control set Type M $7822 \mathrm{NLC}$ (Mostec, Liestal, Switzerland). Contanination of the reservoir was prevented by a heat trap; reservoir and trap were kept under $\mathrm{N}_{2} / \mathrm{CO}_{2}(90 \% / 10 \%)$ at 50 mbar pressure. Growth was followed at $436 \mathrm{~mm}$ in 1-ml cuvettes.

\section{Enzyme assay}

Ceil-free extracts were prepared from malate-grown cells harvested in the late log-phase; either by incubalion with lysozyme $\left(2 \mathrm{mg} \cdot \mathrm{m}^{-1}\right.$ ) in a $50 \mathrm{mM}$ phosphate bulfer, $\mathrm{pH} 7.2$, with $1 \mathrm{mM}$ $\mathrm{MgCl}_{2}$ at $35^{\circ} \mathrm{C}$ for $30 \mathrm{~min}$, or by French press cell treatment at $6.9 \mathrm{MPa}$. After centrifugation at $20000 \times g$ for $20 \mathrm{~min}$. the clcar supernatant (crude extract) was used either directly for enzymatic studies, or was further subtractionated by centrifugation at $120000 \times g$ for 40 miti.

Malo-lactic enzyme was measured via $\mathrm{CO}_{2}$ formation either manometrically (Caspritz and Radler 1983 ) or by gas chromato graphy (Platen and Schink 1990). The test was carried out anoxically at $25^{\circ} \mathrm{C}$ in 25 -ml serun tubes sealed with butyl rubber stoppers; 300-u1 samples were taken at intervals from the headspace after shaking. Standards were prepared witl a $100 \mathrm{mM} \mathrm{NaHCO}_{3}$ solution.

Lactate dehydrogenase (E.C. 1.1.1.27) and malate dehydrogenase (E.C. 1.1.1.37), were determined after Bergmeyer (1974). Oxaloacetate decarboxylase was assayed after Dimroth (1981), malate dehydrogenase, oxaloacetate decarboxylating ("malic enzyme", E.C. 1.1.1.39) after London and Meyer (1969).
Chemical analyses

Acetate and ethanol were assayed by gas chromatography as described (Dehning et al. 1989). DL-malate and bu-Jactate were quantified etther enzymatically (Rergmeycr 1984, 1985) or by capillary gas chromalography of their methyl esters with malonate as internal standard (Dchning and Schink 1989b).

Protem was quantified by a micro-biuret method (Zamenhoff 1957) with bovine serum albumine as standard.

\section{Chemicals}

All chemicals used were of analytical grade and obtained from Fluka, Neu-Ulm. and Merck, Darmstadt, FRG. Brochemicals were purchascd from Bochringer, Mannheim, and Sigma, München, FRG. Gases were obtained from Messer-Griesheim, Frankfurt. FRG.

\section{Results}

\section{Malate utilization by lactic acid bacteria}

Lactic acid bacteria are usually cultivated in rather complex media (e.g. Evans and Niven 1951; de Man et al. 1960). Studies on a possible energy conservation from malate utilization required a comparably poor growth medium which allowed determination of small growth yield increases over background growth. Experiments with Lactobacillus plantarum revealed that a mineral medium supplemented with trace elements, 7 vitamins, and $0.1 \%$ yeast extract allowed reliable growth with constant growth yields with glucose ( $\mathrm{Y}=24-28 \mathrm{~g} \cdot \mathrm{mol}$ glucose $^{-1}$ ) up to $10 \mathrm{mM}$ initial concentration. The medium could be buffered efficiently at $\mathrm{pH} 6.4$ with $20 \mathrm{mM}$ potassium phosphate, or at $\mathrm{pH} 5.0$ with $20 \mathrm{mM}$ sodium succinate.

Seven different strains of lactic acid bacteria were checked in succinate-buffered medium for utilization of malate. As shown in Table 1, only Lactobacillus sake and L. plantarum converted malate ncarly stoichiometrically to lactate with significant growth. $L$. casei and $L$. coryniformis carried out basically the same fermentation but growth was considerably lower. No growth during lactate utilization was observed with Lactobacillus sp., Leuconostoc mesenteroides, or Strepiococcus faecalis. Growth experiments at $\mathrm{pH} 6.4$ with phosphate-buffered medium yielded basically similar results, but malate-dependent growth yields were slightly higher with $L$. casei and L. coryniformis (results not shown). Cultivation in lowsodium $\left(<0.1 \mathrm{mM} \mathrm{Na}{ }^{-}\right.$) media had no influence on growth rates or yields. $L$. sake and $L$. plantarum both used only the L-enantiomer of D,L-malate, and converted it exclusively to L-lactate. Contrary to L. sake, L. plantarum exhibited cell autolysis only after prolonged incubation for more than 2 days beyond growth cessation, and was therefore used in the following growth experiments.

Variation of yeast extract versus malate supply with L. plantarim (Fig. 1) demonstrated that yeast extract supported growtil as energy and cell carbon source independent of malatc addition. Malate, on the other 
Table 1. Malatc transformation and malate-dependent growth of various lactic acid bacteria at $\mathrm{pH} 5.0$

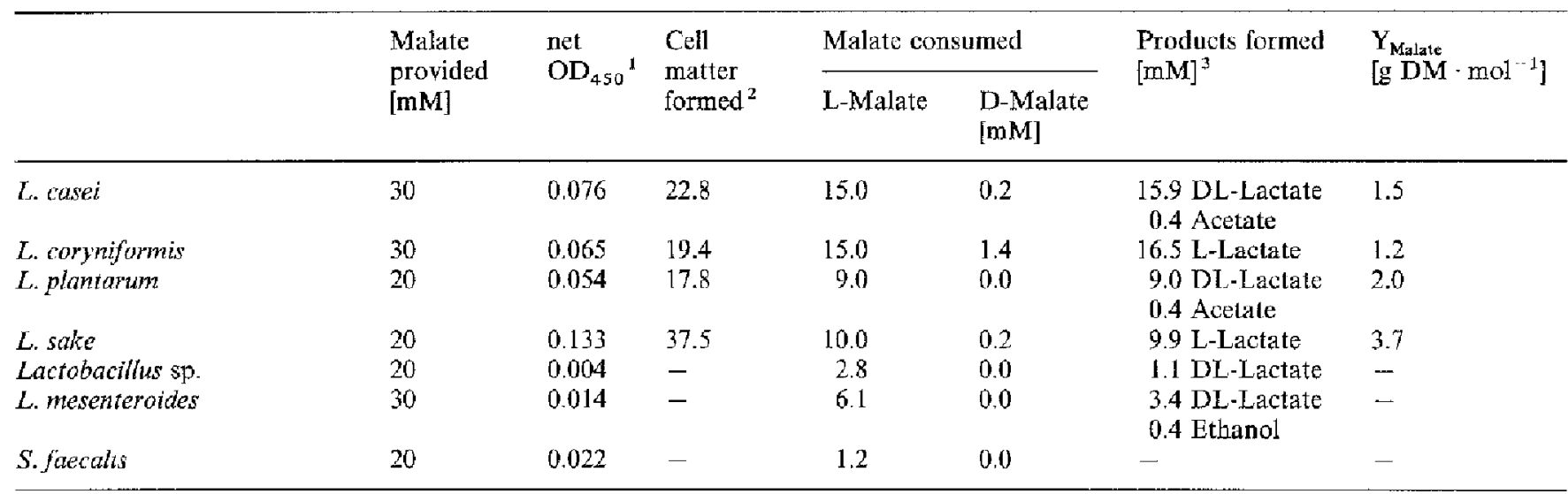

Experiments were carried out in 22-ml screw-cap tubes

1 net $\mathrm{OD}$ is $\mathrm{OD}$ of the experimental tubes minus that reached in malate-free control tubes

${ }^{2}$ Cell dry matter was calculated via cell turbidity using the experimentally determined conwcrsion lactors $0.1 \mathrm{OD}_{450}$ $=29.7 \mathrm{mg}$ dry matter per liter (L. mesenteroides), $33.5 \mathrm{mg}$ dry matter per liter ( $L$. spec.), $36.0 \mathrm{mg}$ dry mass per liter ( $S$. fuccalis,
$30.0 \mathrm{mg}$ dry mass per liter (L. casei), $29.8 \mathrm{mg}$ dry mass per liter (L. coryniformis), $33.1 \mathrm{mg}$ dry mass per liter (L.plantarum), $28.2 \mathrm{mg}$ dry mass per liter (L. sake)

${ }^{3} \mathrm{D}, \mathrm{L}$-Lactate, acetate, ethanol and propionate were assayed in all samples. Net product concentrations were calculated as differences of test tubes vs. malate-free control tubes. Concentrations $<0.3 \mathrm{mM}$ are not listed hand, could serve as energy source only if at least $0.1 \%$ yeast extract was provided which was probably mainly assimilated into cell material. Similar results were abtained with $L$. sake (nol shown).

Growth of L. plantarum with $15 \mathrm{mM} \mathrm{M}$-malate in the presence of $0.1 \%$ yeast extract was followed in $\mathrm{pH}-$ controlled batch fermentor cultures at $\mathrm{pH}$ 5.7. Initial growth after inoculation was fast and mainly due to yeast extract fermentation (Fig. 2a). In a second growth phase between 5 and $15 \mathrm{~h}$ after inoculation, malate was converted stoichiometrically to lactate and trace amounts of acetate. Growth was considerably slower through this phasc, and ceased nearly completely alter about $7 \mathrm{mM}$ malate was degraded. In the last phase, the leftover malate was converted to lactate without significant growth (Fig. 2a). Also in this culture system, malatedependent growth correlated strictly with the amount of malate provided, and lactate was found as nearly only product, together with traces of acetate (Fig. 2b).

\section{Continuous cuiture and product inhibition experiments}

In continuous culture with $5 \mathrm{mM}$ glucose as substrate (results not shown), L. plantarum grew well with nearly constant growth yields at various dilution rates. The maximum growth rate reached reproducibly was $0.483 \mathrm{~h}^{-1}\left(\mu_{\mathrm{max}}=1.4 \mathrm{~h}\right.$ ). The growth yield was between 24.8 and $26 \mathrm{~g}$ dry matter per mol glucose; the maintenance coefficient $m_{F}$ was determined to $1.67 \cdot 10^{-4}$ $\pm 0.3 \cdot 10^{-4} \mathrm{~mol}$ glucose per gram dry matter.

Similar experiments with $\mathrm{D}, \mathrm{L}-\mathrm{malate}$ as substrate yiclded basically different results. Fig. 3 shows the dependence of optical density, leftover substrate, and products formed on incrcasing concentrations of malate provided in the reservoir. In all cases, equilibrium states are plotted which were reached after at least 3 full medium exchanges at a dilution rate of $0.027 \mathrm{~h}^{-1}$ corresponding to about $0.5 \mu_{\max }\left(\mu_{\max }=0.066 \mathrm{~h}^{-1} \pm 0.005 \mathrm{~h}^{-1}\right.$ was determined for growth with malate in washout experiments). At

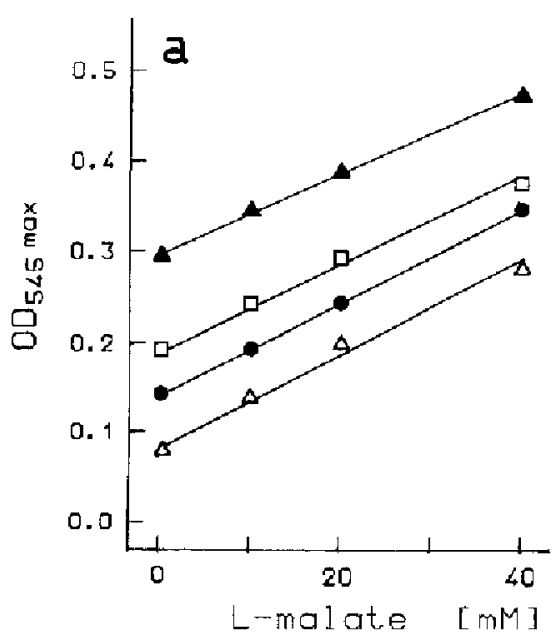

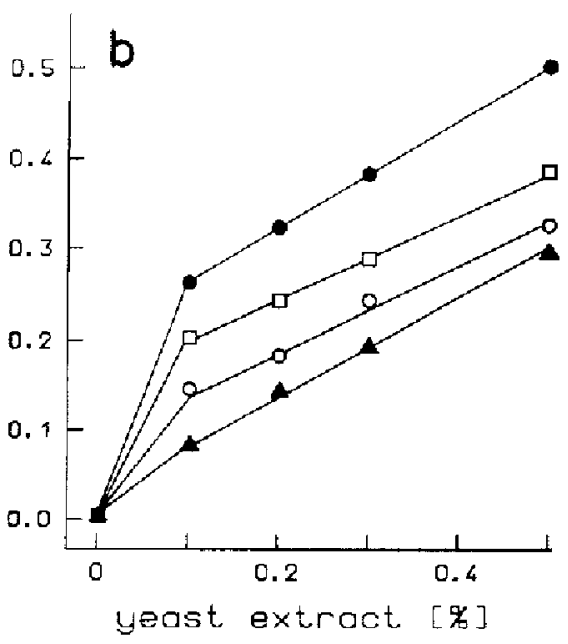

Fig. 1a, b. Growth of Lactobacillus plantarum in minimal medium, $\mathrm{pH}$ 5.0, with L-malate and yeast extract. Maximum OD values reached are shown. a Variation of L-malate provided with constant amounts of yeast extract. ( $\Delta$ ) $0.1 \%$, (৫) $0.2 \%$, (ㅁ) $0.3 \%$, (A) $0.5 \%$ yeast extract in the modium background. b Yariation of yeast extract provided with constant amounts of malate. (c) $0 \mathrm{mM}$, (o) $10 \mathrm{mM}$, () $20 \mathrm{mM}$, (4) $40 \mathrm{mM}$ L-malate in the medium background 


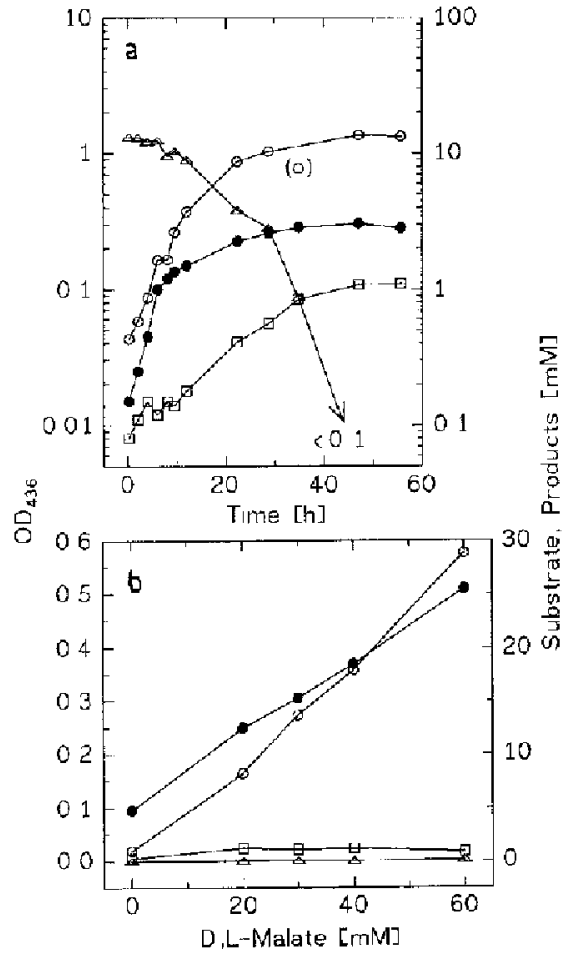

Fig. 2a. Growth of Lactobacillus plantarum in pH-controlled batch culture at $\mathrm{pH} 5.7$ with $30 \mathrm{mM}$ D,L-malate in the presence of $0.1 \%$ yeast extract Optical density, product and substrate concentration are plotted on a logarithmic scale. ( Optical density, ( $\Delta$ ) L-malale, (O) L-lactate, ( $\square$ ) acetate. b Malate-dependent growth of Lactobacillus plantorum in $\mathrm{pH}$-controlled batch culture. ( ) Optical density, (A) L-malate, (O) L-lactate, (D) acetate

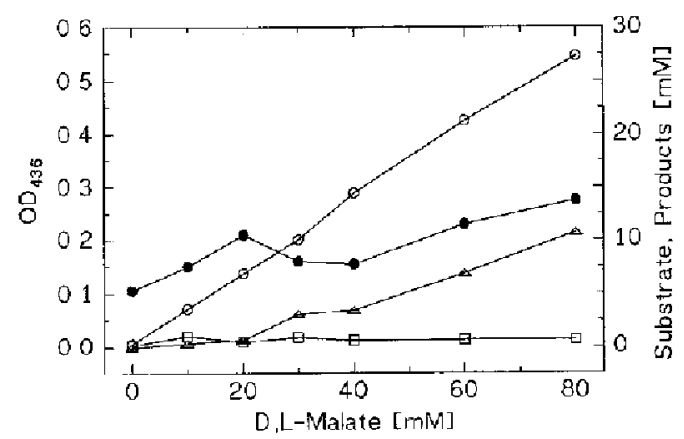

Fig. 3. Growth of $L$. plantaram with D,L-malate at various concentrations in continuous culture at $\mathrm{pH}=5.7$. The dilution rate $\mathrm{D}$

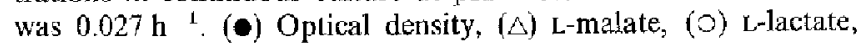
(口) acetate

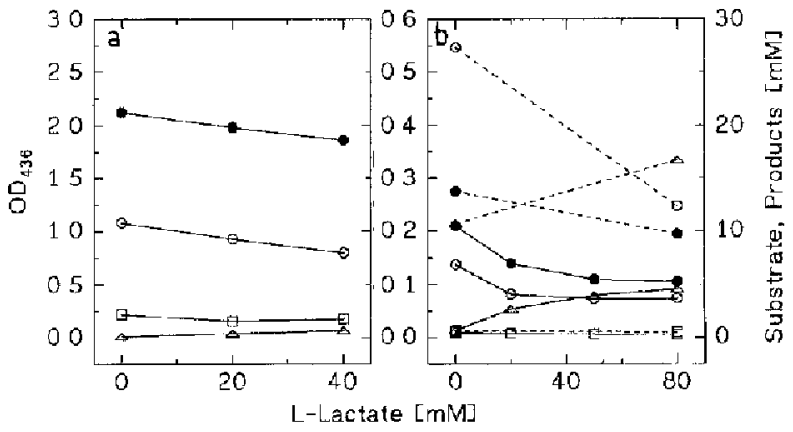

Fig. 4a, b. Effect of added L-lactate on growth and substrate utilization by Lactobacillus plantarm in continuous culture at $\mathrm{pH}=5.7 ;$ a $5 \mathrm{~m} \mathrm{M}$ D-glucose as substrate, dilution rate $\mathrm{D}=0.184 \mathrm{~h}^{-1} ;$ b $10 \mathrm{mM}$ (solid lines) or $40 \mathrm{mM}$ (dashed lines) D.I-malate as substrate, dilution rate $\mathrm{D}=0.027 \mathrm{~h}^{-1}$. (4) Optical density, ( $\Delta$ ) L-malate, (O) L-lactate, ( $($ ) acetate

D, L-malate concentrations lower than $20 \mathrm{mM}$, the optical density increased slightly less than in batch cultures, with a specific growth yield of $1.44 \mathrm{~g}$ dry matter per mol malate. L-malate was used up nearly completely, and the L-lactate concentration increased linearly (Fig. 3). At higher malate concentrations provided, the formed I-lactate increased as well, but more and more L-malate accumulated unused in the fermentor. The optical density did not increase any further but remained in the same range as with $20 \mathrm{mM}$, L-malate.

To check for effects of accumulating lactate on substrate conversion and cell yields, L. plantarum was cultivated in $\mathrm{pH}$-controlled continuous cultures at $\mathrm{pH} 5.7$ with glucose or malate as substrate, in the presence of varying amounts of $\mathrm{L}$-lactate in the reservoir. With $5 \mathrm{mM}$ glucose as substrate, $20 \mathrm{mM}$ added I-lactate decreased growth by $6 \%$ and lactate production by about $12 \%$ (Fig. 4a). Glucose was used up completely to the detection limit. The effect of added lactate on malate utilization was more dramatic (Fig. 4b): With $10 \mathrm{mM}$ L-malate as substrate, $20 \mathrm{mM}$ added L-lactate decreased growth yields by $33 \%$ and lactate formation by $41 \%$; the remnant malate accumulated in the reactor. Higher lactate additions decreased yields and product formation further, but never completely. With $40 \mathrm{mM}$ L-malate as substrate, similar effects were observed (Fig. 4b). Acetate was not formed to significant amounts.

\section{Enzyme measurements}

Enzymes possibly involved in malate conversion to lactate were determined in crude cell extracts of $L$.
Table 2. Specific activities of malate-transforming enzymes in cell-free extracts of Lactobacillus sake and Lactobacillus plantarum. All cnyme activities were found to more than $96 \%$ in the cyloplasmic fraction

\begin{tabular}{llcc}
\hline Enzyme & E.C. number & L. sake & L. plantarum \\
\hline Malate dehydrogenase & 1.1 .1 .37 & $<0.1$ & 0.035 \\
Malate dehydrogennse, oxalo- & 1.1 .1 .40 & $<0.1$ & 0.16 \\
$\quad$ acetate-decarboxylating & 4.1 .1 .3 & n.d. & $<0.1$ \\
Oxaloacetate decarboxylase & $?$ & 22.0 & 0.90 \\
Malo-lactic enzyme & &
\end{tabular}

Enzyme activities are listed as $\mu \mathrm{mol} \cdot \mathrm{min}^{-1} \cdot \mathrm{mg}^{-1}$ protein 
plantarum and L. sake. As shown in Table 2, neither malate dehydrogenase, malic enzyme, nor oxaloacetate decarboxylase was found at significant activities. Only the malo-lactic enzyme which decarboxylates malate directly to lactate without release of oxaloacetate was found at high activity, especially in L. sake. The malo-lactic enzyme was found to more than $96 \%$ in the cytoplasmic fraction of the respective cells tested, and was not inhibited by avidin. The malate-degrading activity of L. plantarum cells growing with malate at maximal rate is $0.55 \mu \mathrm{mol} \cdot \mathrm{min}^{-1} \cdot \mathrm{mg}^{-1}$ protein.

\section{Discussion}

\section{Growth by malo-iactic fermentation}

In the present communication, growth of lactic acid bacteria on the basis of malolactic fermentation is documented for the first time. This is as well the first unequivocal proof that malate conversion to lactate can be coupled with energy conservation. This observation became possible only because a comparably poor growth medium was applied which allowed measurement of the small energy gain in cell mass by this reaction; earlier reports claiming that malo-lactic fermentation is not coupled to energy conservation were based on experiments with very rich media (Pilone and Kunkee 1976) containing in addition e.g. $100 \mathrm{mM}$ glucose as background substrate (Kandler et al. 1973). However, for detection of small energy gains it is necessary to cultivate bacteria in substrate-limited cultures. The growth media used in the present study contained $1.0 \mathrm{~g} \cdot 1^{-1}$ yeast extract as sole undefined medium constituent. We could not replace yeast extract entirely by defined components to achieve reliable growth with all strains examined. Nonetheless, variation of the amounts of yeast extract against malate proved that yeast extract served mainly for assimilatory purposes, and that at least at higher malate-to-yeast extract ratios energy metabolism was entirely fueled by malo-lactic fermentation. The glucosespecific growth yields obtained with this medium were in the same range as those obtained in complex media (de Vries et al. 1970) indicating that growth in our medium was not limited by any unknown component.

These results confirm reports on enhanced ATP synthesis in the presence of malate by Leuconostoc oenos (Cox and Henick-Kling 1989), and help to explain the observation that growth rates of $L$. oenos increased in the presence of malate. especially at lower $\mathrm{pH}$ conditions (Pilone and Kunkee 1976). However, not all lactic acid bacteria tested in our study exhibited malate decarboxylation-dependent growth: only L. plantarum and L. sake combined this decarboxylation reaction with significant cell malter production. Nonetheless, the two growthpositive Lactobacillus strains are important constituents of the bacterial flora in wine, and have been found among the predominant species in several different fermenting wines (Kunkee 1967; Renault and Heslot 1987; Sieiro et al. 1990). Malate decarboxylation-dependent growth may be of ecological importance in this environment, therefore, and this even more so because the free energy change of this reaction increases with higher proton activity: If we assume about equal concentrations of malate and lactate (Radler 1986) and $\mathrm{CO}_{2}$ at 1 bar pressure, the free encrgy change at $\mathrm{pH} 7.0$ is

malate $^{2-}+\mathrm{H}^{+} \rightarrow$ lactate ${ }^{-}+\mathrm{CO}_{2}$, $\Delta \mathrm{G}^{0}=-26.5 \mathrm{~kJ} \cdot \mathrm{mol}^{-1}$,

and increases to $-33.9 \mathrm{~kJ} \cdot \mathrm{mol}^{-1}$ at $\mathrm{pH} 5.7$ (growth conditions mainly applied in this study) or to $-46.5 \mathrm{~kJ}$ $\times \mathrm{mol}^{-1}$ at $\mathrm{pH} 3.5$, the $\mathrm{pH}$ typically prevailing in young wines. It is not surprizing, therefore, to find that bacteria actually exploit this energy span, at least to help maintain the comparably bigh proton gradient across the cytoplasmic membrane under such growth conditions.

\section{Biochemistry of energy conservation}

Two different systems for conservation of decarboxylation encrgy in microbial metabolism have been described so far: i) in oxaloacetate decarboxylation by Klebsiella aerogenes (Dimroth 1980), methylmalonyl CoA decarboxylation by Veillonella alcalescens (Hilpert and Dimroth 1983) and Propionigenizm modesizm (Hilpert et al. 1984), and in glutaconyl CoA decarboxylation by c.g. Acidaminococcus fermentans (Buckel and Semmler 1982), the respective decarboxylating enzyme is membrane-bound and acts as a primary sodium pump to conserve the energy in a sodium ion gradient actoss the cytoplasmic membrane. ii) In oxalate fermentation to formate and $\mathrm{CO}_{2}$, the decarboxylating enzyme is localized in the cytoplasm, and the decarboxylation energy is conserved indirectly by an electrogenic oxalate/formate antiporter system (Anantharam et al. 1989).

Enzyme measurements in cell-free extracts of $L$. plantarum and $L$. sake revealed that only the malo-lactic cnzyme was present at activities sufficient to carry out malate decarboxylation at the observed rates. No oxaloacetate decarboxylase, malic enzyme, or malate dehydrogenase was found at significant activity. The malo-lactic enzyme was detected entirely in the cytoplasmic fraction, and there was no indication of membrane association as already reported by other authors (Schütz and Radler 1973; Caspritz and Radler 1983). However, this is not a reliable proof because membrane-associated enzymes are easily sheared off the membranes through the preparation process (e.g. Abrams 1965; Rohde et al. 1984). Malatedependent growth of both Lactobacillus strains was not impaired in low-sodium medium indicating that sodium ions were probably not involved in this energy conservation system. All these results support the assumption that energy conservation in malo-lactic fermentation is due to substrate/product transport rather than to a sodium pumping decarboxylase enzyme.

This hypothesis is further corroborated by the observed product inhibition of malate transformation and associated growth. Although cell yields increased linearly with provided malate in batch culture experiments, growth did not parallel malate conversion to lactate 
through the entire growth curve: After transformation of about $60-70 \%$ of the provided malate, growth ceased while malate was still transformed to lactate. Obviously, decarboxylation-dependent energy conservation operated best at a high substrate-to-product ratio, and became inefficient when this ratio fell under a certain limit. This observation gave a first hint that substrate import or product export could have key functions in this type of energy conservation.

We therefore started growth experiments in a chemostat because in this culture system the bacterium has to operate always at limiting substrate concentration against the full corresponding product concentration (Veldkamp 1977). Growth of L. plantarum in the chemostat was not directly correlated with the malate concentration provided in the reservoir, bul exceeded yeast cxtract-dependent growth only slightly. Nonetheless, malate was still decarboxylated to lactate, howcver, not completely, and leftover malate accumulated in the reactor at a certain ratio over the lactate formed, as typical of cultures under the influence of product inhibition (Pirt 1975). Since this effect was expressed much more severely with malate than with glucose as substrate, it is obvious that product efllux plays an essential and specific role in energy conservation by malolactic fermentation. Energy conservation coupled to lactate efflux in lactic acid bacteria has been hypothesized repeatedly on the basis of convinoing indirect experimental evidence (Michels et al. 1979; Otto et al. 1980; ten Brink and Konings 1982; Konings and Veldkamp 1980, 1983). On the other hand, Propionigenium modestum which conserves decarboxylation energy by a primary sodium pump can be grown in continuous culture at constant yields at various substrate concentrations (B. Schink, unpublished).

Substrate import, on the other hand, cannot contribute significantly to the energy budget in malo-lactic fermentation because the substrate affinities of the described malolactic enzymes are far too low ( $K_{\mathrm{m}}$ for malate at 9.5 and $16.7 \mathrm{mM}$ with L. plantarum and L. mesenteroides, respectively; Caspritz and Radler 1983; Lonvand-Funel and Strasser de Saad 1982) to establish an energy-yielding substrate gradient across the membrane. Rather, malate transport across the cytoplasmic membrane appears to be an electroneutral symport with protons, at least in the yeast Hansemula anomala (CorteReal and Leão 1990). One could also think of an electrogenic malate/lactate antiporter as a means of energy conservation as suggested by Poolman (1990), analogous to the oxalate/formate antiporter of Oxalobacter formigenes (Anantharam et al. 1989). For the reason mentioned before, such a system would need to recruit its encrgy mainly from a high inside-to-outside lactate gradient in the range of 1000: 1 in order to obtain the minimum energy unit of one third of an ATP equivalent (around $20 \mathrm{~kJ} \cdot \mathrm{mol}^{-1}$ ) for ATPase-dependent ATP synthesis (Schink 1990). Obviously, this is possible only at an carly stage in batch culture and hardly ever in continuous culture. The growth yields of malo-lactic fermentation determined in batch culture are mainly established during the initial substrate conversion phase, thereforc, and are in general smaller than those obscrved with decarboxylation fermentations depending on primary sodium pumps.

Acknowledgements. The authors are indebted to Prof. Dr. R. K. Thauer for fruitful discussions and helpful suggestions. This study was financially supported by a grant of the Deutsche Forschungsgemeinschaft.

\section{References}

Abrams A (1965) The release of bound adenosine triphosphatase from isolated bacterial membranes and the properties of the solubilized enzyme. J Biol Chem 240: 3675-3681

Anantharam V, Allison MJ, Maloney PC (1989) Oxalate: formate exchange. The basis for cnergy coupling in Oxalobarter. I Biol Chem 264: 7244-7250

Bergmeyer HU (1974) Methoden der enzymatischen Analyse, 3rd edn. Verlag Chemie, Weinheim

Bergmeyer HU (1984/1985) Methods of enzymatic analysis, 3rd edn., vols VI, VII. Verlag Chemie, Weinheim

Brink B ten, Konings WN (1982) Electrochemical proton gradient and lactate concentration gradient in Streptococcus cremoris cells grown in batch culture. J Bacteriol 152: 682-686

Buckel W, Semmler R (1982) A biotin-dependent sodium pump: glutaconyl-CoA decarboxylase from Acidaminococcus fermentans. FIBS Lett 148: 35-38

Caspritz G, Radler F (1983) Malolactic enzyme of Lactobacillus plantaram. Purification, properties, and distribution among bacteria. J Biol Chem 258: 4907-4910

Corte-Real M, Leão C (1990) I ransport of malic acid and other decarborylic acids in the yeast Hansenula anomala. Appl Environ Microbiol 56: 1109-1113

Cox DJ, Henick-Kling T (1989) Chemiosmotic energy from malolactic fermentation. J Bacteriol 171: 5750-5752

Davis CR, Wibowo DJ, Eschenbruch R, Lee TH, Flect GH (1985) Practical implications of malolactic fermentation: a review. Am J Enol Viticult 36: 290-301

Dawson KA, Nllison MJ. Hartman PA (1980) Isolation and some characteristics of anaerobic oxalate-degrading bacteria from the rumen. Appl Environ Microbiol 40: 833-839

Dehning I, Stieb M, Schink B (1989) Sporomusa malonica sp. nov., a homoacetogenic bacterium growing by decarboxylation of malonatc or succinate. Arch Microbiol 151: 421.426

Dehning I, Schink B (1989a) Two new species of anaerobic oxalate-fermenting bacteria, Oxalobucter vibrioformis sp. nov. and Clostridium oxalicum sp. nov. Arch Microbiol 153: 79-84

Dehning I, Schink B (1989b) Malonomonas rubra gen. nov. sp. nov., a microacrotolerant anaerobic bacterium growing by decarboxylation of malonate. Arch Microbiol 151:427-433

Denger K, Schink B (1990) New motile anaerobic bacteria growing by succinate decarboxylation to propionate. Arch Microbiol 154: $550-555$

Dimroth P (1980) A new sodium-transport system energized by the decarboxylation of oxaloacetate. FEBS Lett 122: 234--236

Dimroth P (1981) Characterization of a membrane-bound biotincontaining enzyme: oxaloacetate decarboxylase from Klebsiella aerogenes. Eur J Biochem 115: 353-358

Doelle HW (1975) Bacterial metabolism. 2nd edn. Academc Press, New York

Evans JB, Niven CF (1951) Nutrition of the heterofermentative lactobacilli that cause grecning of cured meat products. I Bacteriol $62: 599-603$

Gottschalk G (1979) Bacterial metabolism, 1st edn. Sprınger, New York

Gottschalk G (1986) Bacterial metabolism, 2nd edn. Springer, New York Berlin Heidelberg 
Hilpert W, Dimroth P (1983) Purification and characterization of a new sodium transport decarboxylase. Methylmalonyl-CoA decarboxylase from Veillonella alcalescens. Eur J Biochem 132: $579-587$

Hilpert W, Schink B, Dimroth P (1984) Life by a new decarboxylation-dependent energy conservation mechanism wilh $\mathrm{Na}^{+}$as coupling ion. EMBO J 3: $1665-1670$

Kandler O, Winter I, Stetter KO (1973) Zur Frage der Beeinflussung der Glucosevergärung durch L-Malat bei Leuconostoc mesenteroides. Arch Mikrobiol 90: 60-75

Koch A (1898) Über die säureverzehrenden Orgarismen des Weines. Weinbau Weinhandel 16:236. 243-245

Koch A (1900) Úber die Ursachen des Verschwindens der Säure bei Gährung und Lagerung des Weines. Weinbau Weinhandel 18: $395-396,407-408,417419$

Konings WN. Veldkamp $\mathrm{H}$ (1980) Phenotypic responses to environmental change. In: Ellwood DC, Hedger JN, I atham MJ, Lynch JM, Slater JH (eds) Contemporary microbial ecology Academic Press, London, pp 161-191

Konings WN, Veldkamp H (1983) Energy transduction and solute transport mechanisms in relation to environments occupied by microorganisms. In : Slater JI, Whittenbury R, Wimpenny JWT (eds) Microbes in their natural environments. Cambridge University Press, Cambridge, pp 153.186

Kunkee R. (1967) Malo-lactic fermentation. Adv Appl Microbiol 9: $235-279$

London J, Meyer EY (1969) Malate utilization by a group D Streptococcus: physiological properties and purification of an inducible malic enzyme. J Bacteriol 98: 705-711

Lonvand-Funel A, Strasser de Saad AM (1982) Purification and properties of a malolactic enzyme from a strain of Leuconostoc mesenteroides isolated from grapes. Appl Environ Microbiol 43: $357-361$

Man JC de, Rogosa M, Sharpe ME (1960) A medium for the cultivation of lactobacilli. J Appl Bacteriol 23: 130-135

Matthies C, Schink B (1992) Fermentative degradation of glutarate via decarboxylation by newly isolated strictly anderobic bacteria. Arch Microbiol 157: 290296

Michels PAM, Michels JPJ, Boonstra J, Konings WN (1979) Generation of an electrochemical proton gradient in bacteria by the excretion of metabolic end products. FEMS Microbiol Lett 5: 357-364

Müller-Thurgau H, Osterwaldor A (1913) Die Bakterien im Wein und Obstwein und die dadurch verursachten Veränderungen. Zentralbl Bakteriol Parasitenkd Hyg Abt II 36: 129-338

Otto R, Sonnenberg ASM, Veldkamp H, Konings WN (1980) Generation of an electrochemical protots gradient in Streptococcus cremoris by lactate efflux. Proc Nat Acad Sci USA 77: $5502-5506$

Pilone GJ, Kunkee RE (1976) Stimulatory effect of malo-lactic fermentation on the growth rate of Leuconostoc oenos. Appl Environ Microbiol 32: 405-408

Pirt SJ (1975) Principles of microbe and cell cultivation. Blackwell Scientific Publ, Oxford
Platen H, Schink B (1990) Enzymes involved in anaerobic degradation of acetone by a denitrifying bacterium. Biodegradation 1 : $243-251$

Poolman B (1990) Precursor/product antiport in bacteria. Mol Microbiol 4: 1629-1636

Radler F (1986) Microbial biochemistry. Experientia 42: 884 893

Renault P, Heslot II (1987) Selection of Streptococctis lactis mutants defective in malolactic fermentation. $\Lambda$ ppl Environ Microbiol $53: 320-324$

Rohde M. Mayer F, Meyer O (1984) Immunocy tochemical localization of carbon monoxide oxidase on Pseudomonas carboxydovorans. The enzyme is attached to the inner aspect of the cytoplasmic membrane. J Biol Chem 259: 14788-14792

Schink B (1990) Conservation of small amounts of energy in fermenting bacteria. In: Finn RK, Präve P (eds) Biotechnology focus 2. Hanser, Munich Vienna, pp 63-89

Schink B, Pfennig N (1982) Propionigenitum modestum gen. nov. sp. nov., a new strictly anaerobic, nonsporing bacterium growing on succinate. Arch Microbiol 133:209-216

Schütz M, Radler F (1973) Das Vorkommen von Malatenzym und Malo-Lactat-Enzym bei verschiedenen Milchsäurebakterien. Atch Mikrobiol 96: 329-339

Sieiro C, Cansado J, Agrela D, Velasquez JB, Vila TG (1990) Isolation and enological characterization of malolactic bacteria from the vineyards of Northwestern Spain. Appl Environ Microbiol 56: 2936-2938

Smith RL, Strohmaier FE, Oremland RS (1985) Isolation of anaerobic oxalate-degrading bacteria from freshwater lake sediments. Arch Microbiol 141: 8-13

Thauer RK, Jungermann K, Decker K (1977) Energy conservation in chemotrophic anaerobic bacteria. Bacteriol Rev 41: 100-180

Veldkamp H (1977) Ecological studies with the chemostat. Adv Microbiol Ecol 1: 59-94

Vries W de, Kapteijn WMC, Beek EG van der, Stouthamer AH (1970) Molar growth yields and fermentation balances of Lactobacillus casei L3 in batch cultures and in continuous cultures. J. Gen Microbiol 63: 333-345

Wibowo D, Eschenbruch RE, Davis CR, Fleet GH, Lee TII (1985) Occurrence and growth of lactic acid bacteria in wine: a review. Am J Enol Viticult 36: 302-313

Widdel F, Prennig N (1981) Studies on dissimilatory sulfatereducing bacteria that decompose fatty acids. I. Isolation of new sulfate-reducing bacteria enriched with acetate from saline environments. Decription of Desulfobacter postgatei gen. nov. sp. nov. Arch Microbiol 129: 395-400

Widdel F, Kohring GW, Maycr F (1983) Studies on dissinilatory sulfate-reducing bacteria that decompose fatty acids. III. Characterization of the filamentous gliding Desulfonema limicola gen. nov. sp. nov, and Desulfonema magntum sp. nov. Areh Microbiol 134: 286-294

7amenhoff S (1957) Preparation and assay of deoxyribonucleic acid from animal tissue. In: Colowick SP, Kaplan NO (eds) Methods in enzymology, vol. 3. Acadenic Press, New York, pp 696-704 